\title{
The effect of emotional labour on work satisfaction and emotional display behaviour
}

\author{
${ }^{1}$ Rury Siti Ruhaniah, ${ }^{2}$ Rayini Dahesihsari \\ ${ }^{1,2}$ Master of Professional Psychology Program, Universitas Katolik Indonesia Atma Jaya, Indonesia \\ ${ }^{1}$ rury.ruhaniah@ymail.com., ${ }^{2}$ rayini@gmail.com.
}

\section{ARTICLE INFO}

Article history

Received 18 October 2017

Revised 01 April 2019

Accepted 04 April 2019

Keywords

emotional display behavior

emotional labour

hospitality industry

job satisfaction

\begin{abstract}
Improving the quality of service in the hospitality industry is a strategic agenda that enables the increase of foreign exchange income. Internal factors affect the quality of service, particularly factors related to emotional processing (emotional labour) of service workers that are associated with the display of an expected emotional expression (emotional display behaviour) when providing services. Furthermore, another essential aspect to consider how to express the expected emotional expression well while also maintaining work comfort (job satisfaction) of the service providers. This research explored the effect of emotional labour on emotional display behaviour and job satisfaction. The study was conducted in a 5-star hotel, involving 94 front liner employees selected through convenience sampling. The study used the Surface and Deep Act Scale, Management Behavior Scale and MSQ-Short Scale. One-way ANOVA was used to analyze the data. The results showed that emotional labour profile had a positive effect on job satisfaction but not on emotional display behaviour. Therefore emotional labour as a personal capital needs to be addressed to enhance job satisfaction.
\end{abstract}

\section{Introduction}

Indonesia's tourism industry is well equipped with a variety of potential natural resources and products of cultural diversity. Many regions across Indonesia have ranked among the world's and Asia's favourite tourist destinations while also being priority tourism destinations by the Indonesian Government, including but not limited to Ubud, Kuta, Mandalika, Danau Toba, Labuan Bajo and Borobudur (Chandra \& Damarjati, 2017). As the second-highest contributor of foreign exchange income and one of the national priorities in Indonesia's 2018 Government Work Plan (RKP), supported by those as mentioned above potential natural resources, this industry requires a strategic agenda. One way to support this target is by increasing competitiveness and competence of human resources in the field of tourism (BAPPENAS, 2017).

Specific to the hotel industry, excellent service, which is supported by optimal HR performance is principally essential, especially for 5-star hotels located in large cities. An example of a 5-star hotel that experienced obstacles in facing these challenges was the AA Hotel, which was established in 1976. In conducting their business, the AA hotel built its identity on Javanese-based service geniality. AA Hotel defines service as a form of service activity that must be done with sincerity, integrity, and devotion. 
Based on the initial interview, it was found that the AA Hotel experienced a decrease in service quality, particularly in the way its employees provide service and express themselves. Interviews with HR, Front Office Manager, and Sales and Marketing Manager showed similar results. For example, some employees had sour expressions even when they were around the guests. As the hotel vanguard, employees are a reflection of the hotel's quality of service due to the nature of their job that requires them to interact directly with the guests. Guests tend to evaluate quality by looking at the sincerity of service, friendliness and empathy of hotel employees, which ultimately has a positive impact on guest satisfaction (Hardiyati, 2010). Optimal service quality can be understood through the concept of emotional display behaviour. Emotional display behaviour is the display of emotional expression at work, which inherently reflects the demands of a particular work position (display rules) (Grandey, Diefendorff, \& Rupp, 2013).

Furthermore, Grandey, Diefendorff, \& Rupp (2013) stated that there are a variety of emotional expressions relative to the main function of service (servicing jobs) with other positions. This is due to the purpose of display rules which not only expedites interaction processes during service transactions and supports the quality of performance but also a company target (Diefendorff, Erickson, Grandey, \& Dahling, 2011).

It is essential to measure emotional display behaviour, which is considered an evident form of display rule due to findings of past studies that employees express emotions in the service delivery process impacts mood and loyalty of guests (Tan, Foo, \& Kwek, 2004;Tsai, 2001). Besides, another study showed that the quality of service provided by employees has a positive effect on general customer satisfaction (Kumadji, Kusumawati, \& Normasari, 2013).

On the other hand, aspects of job satisfaction are often associated with quality of performance, including service quality. For instance, a study by Puspitawati (2014) found that job satisfaction has a positive influence on building excellent service quality. Job satisfaction itself is defined as a positive attitude towards work as a result of one's evaluation of the dimensions and character of his or her job. One who has high job satisfaction will be positive about his or her job, while someone who has low job satisfaction will be negative about his or her job (Robbins \& Judge, 2013).

This leads to the importance of research on aspects that can support the forming of job satisfaction. One study showed that emotional intelligence had a positive influence on job satisfaction (Nuraningsih \& Putra, 2015). This research has become the foundation of the idea that there are internal factors related to the processing of emotions that can affect comfort at work. The emotional labour concept perceives emotions as an essential factor in individual workers.

Emotional labour is a strategy that helps align one's emotional expressions with expectations and goals of the organization he or she works for through two main strategies namely surface acting and deep acting (Grandey et al., 2013). Surface acting is a strategy for managing emotional expressions by modifying the appearance of expected expressions. Deep acting is a strategy for managing emotional expressions through modification of feelings and reassessment.

Based on the above understanding, the concept of emotional labour works at two different levels, namely personal aspects related to the individual's strategy for emotional management and aspects of emotional expressions that are in line with expectations of one's job. Based on this understanding, it is essential to review the relationship between emotional labour and job satisfaction as well as emotional display behaviour.

Several studies that are in line with the above explanation showed that an individual's deep acting strategies could have a significant influence on his or her job satisfaction (Iplik, 
Topsakal, \& Iplik, 2014; Yalcin, 2010). Furthermore, deep acting is positively related to performance and service quality (Kammeyer-Mueller et al., 2013). Findings of several past research related to these two main strategies in emotional labour indicated that deep acting supports the development of comfort at work and supports optimal performance, while surface acting can inhibit the development of comfort at work.

The two emotional labour strategies mentioned above are independent and can be used in a variety of combinations, subsequently forming an emotional labour profile (Gabriel, Daniels, Diefendorff, \& Greguras, 2015). The formation of the four emotional labour profiles is a result of a combination of the different intensities of these two strategies. The four profiles are regulators, deep actors, surface actors, and non-actors. Regulators are individuals who use both strategies in an equally dominant manner. Deep actors and surface actors are individuals who only use one strategy dominantly. Non-actors are individuals who use neither strategies dominantly (Gabriel et al., 2015).

An interesting profile that fits in the hospitality industry is the non-actors profile. Gabriel, Daniels, Diefendorff, \& Greguras (2015) stated that non-actors are positive profiles due to their tendency not to have to make much regulation as they have an innate positive affect within themselves. The same research also found that non-actors have the lowest perception of which emotional display rules is considered appropriate relative to the other profiles. This shows that the demand to display positive emotional expressions is not considered as a burdensome demand because it is already a part of oneself.

Based on these results, it is assumed that the low level of perceived emotional display rules in non-actors can lead to optimal emotional display behaviour with the support of their innate positive affects. Non-actors are perceived to have high job satisfaction because they do not perceive work demands as demands. This is among one of the matters that we want to explore in this study.

From the series of explanations above, there is an expectation towards employees in being able to use emotional management strategies (emotional labour) that allow oneself to show the expected emotional expressions (emotional display behaviour) which in turn can lead to job satisfaction. Thus, this study aimed to see the effect of emotional labour on emotional display behaviour and job satisfaction.

\section{Method}

This study used the convenience sampling technique. Determination of the sample size adheres to the sample size reference table by Sugiyono (2011). Of 122 front liner employees, 94 respondents were involved.

\section{Instrument}

The instrument consisted of a series of questionnaires in the form of a 5-point Likert scale, ranging from $1=$ "Strongly disagree" to $5=$ "Strongly agree". The questionnaire that was used to measure emotional labour was an adaptation of the Surface and Deep Act Scale (Diefendorff, Croyle, \& Gosserand, 2005) with a reliability of .813 and .751, respectively. An example item of the scale is "I try to manage feelings to match the feelings I must show to guests". Table 1 displays a reference table that must be referred to in order to determine one's emotional labour profile. 
Table 1

Standard in Determination of Emotional Labour

\begin{tabular}{lcc}
\hline Profile & Mean Surface Act & Mean Deep Act \\
\hline Regulators & $>3$ & $>3$ \\
Surface Actor & $\geq 3$ & $<3$ \\
Deep Actor & $<3$ & $\geq 3$ \\
Non-Actor & $\leq 2$ & $\leq 2$ \\
\hline
\end{tabular}

Source: Gabriel et al., (2015)

The instrument used to measure emotional display behaviour was adapted from the Emotion Management Behavior Scale (Diefendorff \& Richard, 2003), which had a reliability of .715. An example item of the scale is "I stay positive even when in the face of difficulties". Both instruments were adapted through a back-translation process which involved sworn translators. Lastly, the measurement instrument for job satisfaction was the MSQ Short Form that has been through an adaptation process from English to Bahasa Indonesia in a study conducted by Calista (2017) and had reliability of .835. An example item from the scale is "There are work opportunities that match my ability".

\section{Data Analysis}

Quantitative data analysis techniques were used to analyze the data, namely, descriptive statistics and ANOVA. Descriptive statistics were performed to provide a general description of various demographic factors of the respondent as well as a description of the three variables. ANOVA was used on each dependent variable (One-way ANOVA) to find out the difference between groups.The calculation was done using Statistical of Program for the Social Sciences (SPSS) for Windows version 22.

\section{Results}

There are four identified emotional labour profiles. Table 2 illustrates that the majority of respondents were regulators (33\%), followed by non-actors, surface actors and deep actors, respectively. The percentage gap between regulator, non-actor, and surface actor profiles are not as high as between the deep actor profile and the other three profiles.

The average emotional display behaviour in each group of profiles is relatively similar, ranging between 28-30. In contrast,differences in average job satisfaction are quite visible, ranging between 73-80. Respondents with non-actor profiles have the highest average scores for both variables (emotional display behaviour and job satisfaction). In the satisfied group relative to all the other respondents, $12 \%$ were non-actors, $6 \%$ were regulators, $2 \%$ were deep actors and $2 \%$ were surface actors. Meanwhile, when looking at respondents in the less satisfied category relative to all respondents, $10 \%$ were regulators, $7 \%$ were surface actors and deep actors and non-actors of $3 \%$ each. 
Table 2

Descriptive Results

\begin{tabular}{|c|c|c|c|c|c|c|c|c|c|c|}
\hline \multirow[b]{2}{*}{ Profile } & \multirow[b]{2}{*}{$\mathrm{N}$} & \multirow[b]{2}{*}{$\%$} & \multicolumn{4}{|c|}{ Emotional Display Behavior } & \multicolumn{4}{|c|}{ Job Satisfaction } \\
\hline & & & Mean & $\begin{array}{l}\text { Not good } \\
\text { enough }\end{array}$ & Sufficient & Good & Mean & $\begin{array}{l}\text { Not good } \\
\text { enough }\end{array}$ & Sufficient & Good \\
\hline Non Actors & 27 & $29 \%$ & 29.56 & $5 \%$ & $14 \%$ & $10 \%$ & 80.19 & $3 \%$ & $14 \%$ & $12 \%$ \\
\hline $\begin{array}{l}\text { Surface } \\
\text { Actors }\end{array}$ & 23 & $24 \%$ & 28 & $6 \%$ & $15 \%$ & $3 \%$ & 71.43 & $7 \%$ & $15 \%$ & $2 \%$ \\
\hline Deep Actors & 13 & $14 \%$ & 29.38 & $2 \%$ & $7 \%$ & $4 \%$ & 76.15 & $3 \%$ & $9 \%$ & $2 \%$ \\
\hline Regulators & 31 & $33 \%$ & 29.13 & $8 \%$ & $20 \%$ & $5 \%$ & 73.48 & $10 \%$ & $16 \%$ & $6 \%$ \\
\hline Total & 94 & & & $21 \%$ & $56 \%$ & $22 \%$ & & $23 \%$ & $54 \%$ & $22 \%$ \\
\hline
\end{tabular}

To calculate whether or not there were any significant statistical differences, a statistical test, namely ANOVA, was performed on each dependent variable. Statistical test results are shown in Table 3. The statistical test results in Table 3 show that there is no significant effect of emotional labour profile on emotional display behaviour ( $p>.05$ ). However, there is an effect of emotional labour profile on job satisfaction $(p<.05)$ within effect size of $11.2 \%$.

Post hoc test was done using the Duncan technique to find out which emotional labour profile differentiates the level of job satisfaction. The difference in the mean harmonic value of each sample group indicate whether each sample group in the same or different subset. Duncan's post hoc test results in Table 3 show two different sets of groups were generated from the four groups of sample profiles. Surface actors, deep actors and regulators are in the same group, therefore job satisfaction among these three sample groups are not significantly different. Whereas non-actors sample group is in different groups from surface actors and regulators, so that job satisfation of non-actors sample group is significantly different when compared to surface actors and regulators sample groups. However, non-actors sample group is not significantly different from deep actors because they belong to the same subset

In its relation to results of the descriptive statistics in Table 2, non-actor respondents have a higher average of job satisfaction ( mean $=80.19$ ) compared to regulators' job satisfaction $($ mean $=73.48)$ and surface actors' job satisfaction $($ mean $=$ 71.43).

Table 3

One-way ANOVA and Post Hoc Test

\begin{tabular}{|c|c|c|c|c|c|c|c|c|}
\hline & \multicolumn{3}{|c|}{ Emotional Display Behavior } & \multicolumn{5}{|c|}{ Job Satisfaction } \\
\hline & \multirow[t]{2}{*}{ Sig. } & \multirow{2}{*}{$\begin{array}{c}\text { Adjusted } \\
\text { R } \\
\text { Squared }\end{array}$} & \multirow[t]{2}{*}{ Annotation } & \multirow[t]{2}{*}{ Sig. } & \multirow{2}{*}{$\begin{array}{c}\text { Adjusted } \\
\text { R } \\
\text { Squared }\end{array}$} & \multicolumn{2}{|c|}{ Post Hoc } & \multirow[t]{2}{*}{ Annotation } \\
\hline & & & & & & Subset 1 & Subset 2 & \\
\hline $\begin{array}{l}\text { Emotional } \\
\text { Labor Profile }\end{array}$ & .378 & .001 & $\begin{array}{l}\text { Not } \\
\text { significant }\end{array}$ & .003 & .112 & - & - & Significant \\
\hline Non Actors & & & & & & - & 80.1852 & $\begin{array}{l}\text { Difference } \\
\text { found }\end{array}$ \\
\hline Surface & & & & & & 71.4348 & - & Difference \\
\hline Actors & & & & & & & & found \\
\hline Deep Actors & & & & & & 76.1538 & 76.1538 & $\begin{array}{l}\text { Difference } \\
\text { not found }\end{array}$ \\
\hline Regulators & & & & & & 73.4839 & - & $\begin{array}{l}\text { Difference } \\
\text { found }\end{array}$ \\
\hline
\end{tabular}


Figure 1 is a summary of the effect of emotional labour on emotional display behaviour and job satisfaction based on the results of this study.

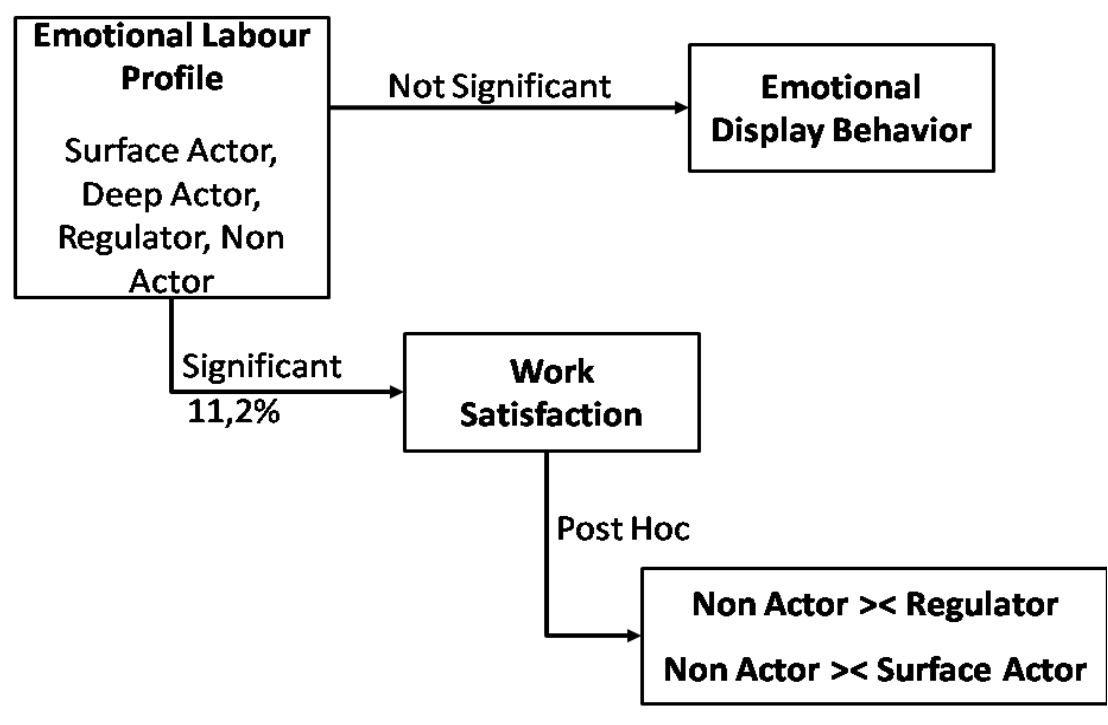

Figure 1.The Effect of Emotional Labor Profile on Emotional Display Behavior and Job Satisfaction

\section{Discussion}

The results of this study indicate that emotional labour affects employee job satisfaction but does not affect employee emotional display behaviour. Respondents achieve the highest job satisfaction in the non-actor profile group, which indicates that individuals who rarely use expressions or emotional modification strategies tend to have higher satisfaction.

The results of this study reinforce the findings of Gabriel, Daniels, Diefendorff, \& Greguras (2015) who stated that individuals with a non-actor profile are generally positive due to their innate positive affect. Hence non-actors have less tendency to make a lot of regulation. Subsequently, it is implied that those who rarely modify expressions or emotions tend to be more satisfied, especially in terms of making other people comfortable. For example, an individual with a high tendency for empathy or those who are happy to please others can easily display positive emotions without needing to be guided by existing rules that ultimately support job satisfaction. This finding is also supported by Humphrey, Ashforth, \& Diefendorff (2015) who found that when employees are able to identify with their internal roles and can align with them without internal conflict, emotional labour will affirm their identity - ultimately providing a rational basis for the importance of the person-job fit concept.

Furthermore, the results of the post hoc test showed that there were differences in the level of job satisfaction between non-actors and regulators as well as non-actors and surface actors. One similarity that can be drawn is that both regulators and surface actors use surface acting strategies though at different intensities. This indicates that the surface acting strategy may has a negative influence on job satisfaction.

These results support the research of Martínez-Iñigo, Totterdell, Alcover, \& Holman (2007) as well as Iplik et al. (2014) who found that the use of surface acting strategy is predominantly and positively related to emotional exhaustion and burn out. Both studies showed that surface acting leads to uncomfortable work conditions. Other research found that emotional fatigue has a negative influence on job satisfaction 
(Churiyah, 2011). Furthermore, burn out, and job satisfaction also had a negative relationship, meaning that the higher the job satisfaction level, the lower the burn out (Pangemanan, Pio, \& Tumbel, 2017). These studies indicate that the more an individual is accustomed to modifying their expressions without internal emotional management, the more the habit can interfere with work comfort. This, in turn, can lead to low job satisfaction, and may even lead to burning out if it is prolonged.

In terms of emotional labour profile, the majority of respondents were regulators (33\%), followed by non-actors, surface actors, and finally deep actors. In other words, the strategy used by the majority of respondents is repetitive and considered procedural service behaviour, which is combined with a modification of feelings in the face of severe problems or more critical situations.

The majority of respondents are regulators, indicating a combination of deep acting and surface acting strategies, which is a strategy to modify feelings and the appearance of expressions, to display the right expressions tends to be more widely used. Furthermore, deep acting strategy involves reappraisal of certain conditions (Gabriel et al., 2015). This can help employees deal with guest complaints and understand the actual needs of guests.

On the other hand, the second-highest majority of respondents were non-actors. Respondents with this profile do not attempt to use any strategies in managing their expressions. (Gabriel et al., 2015) explained that individuals who have worked a prolonged period or individuals who have relatively stable performance are usually non-actors who have an innate tendency to display positive emotions or expressions. For example, it is easy for employees to display positive expressions if the employee feels comfortable pleasing or serving others.

Surface actor respondents accounted for $24 \%$ of all respondents. Respondents of this group tend to modify their display of expressions without internalization of emotional appreciation. A common behaviour is faking or forcing oneself to smile during unfavorable emotional conditions. Employees who have worked for a long period of time and have internalized and habitualised the appropriate standards of expression are also included in this group. A natural expression or reflex that is displayed to suit demands with no internal emotional modification is considered a surface acting strategy (Gabriel et al., 2015).

Statistical tests indicate that there is no influence of emotional labour profile on the level of emotional display behaviour. This means that no matter whether the level of emotional display behaviour is high or low, the emotional labour profile will not be influenced. This is in line with the results of other studies which found that frontline customer service has a high need for continuous and monotonous superficial emotional display behaviour (Humphrey, Pollack, \& Hawver, 2008). An example of a superficial emotional display behaviour is automatic and consistent smiling without any sense of sincerity as a service standard that needs to be fulfilled whatever the character or personal aspects of the employee. Based on the results of the study, high frequency of having to provide procedural services is not related to internal emotional management (emotional labour).

Furthermore, the majority $(60 \%)$ of AA Hotel employees have worked for more than ten years which enabled certain habits to form during the process. Although it has yet to be discussed in this study, there is room for these habits to support or hinder the emergence of the expected emotional display behaviour. This condition is in line with Diefendorff et al. (2005), who stated that those who have served in their jobs for a lengthy period tend to internalize and execute the display rule. Thus, other conditions allow low variation in values that are related to the achievement of emotional display behaviour. 
The implications of this study can be directed at employees who face obstacles in achieving job satisfaction. Such employees need to be allowed to meet their personal needs in order to manage their emotions using a more appropriate approach. This is worth discussing because when a person's service quality decreases, it does not mean that he/she must automatically be reminded of what is asked of him/her through service excellence or courtesy training that is often provided by the AA Hotel.

Besides surface acting, regulators profiles also use deep acting strategies. One deep acting strategy in the service context is reappraisal, which is a form of evaluation towards one's situation in order to enhance pleasant service and influence guests to provide positive feedback (Yalcin, 2010).

However, the results of this study indicate that differences in emotional labour profiles do not affect the level of emotional display behaviour. The role of perception towards perceived display rule and the manner to which employees display in the form of behaviour as well as its relation to the emotional labour profile can be the foundation of future research.

\section{Conclusion}

Based on the results of this study, it can be concluded that emotional labour profile influences the level of job satisfaction of hospitality employees. More specifically, employees who have internal needs that are in line with work demands lead to lower use of emotional management strategies, which in turn have an impact on high levels of job satisfaction. On the other hand, preference for emotional management strategies (emotional labour) does not affect the use of positive expressions in providing services (emotional display behaviour). In other words, it is necessary for all parties involved in the hotel industry to pay attention to personal aspects, emotional labour profiles, which can support job satisfaction - rigorously maintained until the expected quality of service excellence is achieved.

\section{References}

Calista, C. (2017). Pengukuran beban kerja mental dan kepuasan kerja menggunakan NASA-TLX dan MSQ serta pengaruhnya terhadap kinerja karyawan (Measurement of mental workload and job satisfaction using NASA-TLX and MSQ and its effect on employee performance). Unika Atma Jaya.

Chandra, A. A., \& Damarjati, D. (2017). Tiga Tahun Jokowi-JK, Pariwisata Sumbang Devisa Terbesar Kedua. Retrieved from detikFinance website: https://finance.detik.com/berita-ekonomi-bisnis/d-3687715/tiga-tahun-jokowi-jkpariwisata-sumbang-devisa-terbesar-kedua

Churiyah, M. (2011). Pengaruh konflik peran, kelelahan emosional terhadap kepuasan kerja dan komitmen organisasi (The effect of role conflict and emotional exhausted to job satisfaction and organisational commitment). Jurnal Ekonomi Bisnis, 16, 145154.

Diefendorff, J. M., Croyle, M. H., \& Gosserand, R. H. (2005). The dimensionality and antecedents of emotional labor strategies. Journal of Vocational Behavior, 66(2), 339-357. https://doi.org/10.1016/j.jvb.2004.02.001

Diefendorff, J. M., Erickson, R. J., Grandey, A. A., \& Dahling, J. J. (2011). Emotional display rules as work unit norms: A multilevel analysis of emotional labor among 
nurses. Journal of Occupational Health Psychology, 16(2), 170-186. https://doi.org/10.1037/a0021725

Diefendorff, J. M., \& Richard, E. M. (2003). Antecedents and consequences of emotional display rule perceptions. The Journal of Applied Psychology, 88(2), 284-294. Retrieved from http://www.ncbi.nlm.nih.gov/pubmed/12731712

Gabriel, A. S., Daniels, M. A., Diefendorff, J. M., \& Greguras, G. J. (2015). Emotional labor actors: A latent profile analysis of emotional labor strategies. Journal of Applied Psychology, 100(3), 863-879. https://doi.org/10.1037/a0037408

Grandey, A., Diefendorff, J., \& Rupp, D. E. (2013). Emotional labor in the 21st century: diverse perspectives on the psychology of emotion regulation at work. Retrieved from https://www.routledge.com/Emotional-Labor-in-the-21st-Century-Diverse-

Perspectives-on-Emotion-Regulation/Grandey-Diefendorff-

Rupp/p/book/9781848729490

Hardiyati, R., \& Khasanah, I. (2010). Analisis pengaruh kualitas pelayanan terhadap kepuasan konsumen menggunakan jasa penginapan agrowisata kebun teh pagilaran (Analysis of the effect of service quality on costumer satisfaction using the services of Pagilaran tea garden argo-tourism accomodation). Retrieved from http://eprints.undip.ac.id/23450/

Humphrey, R. H., Ashforth, B. E., \& Diefendorff, J. M. (2015). The bright side of emotional labor. Journal of Organizational Behavior, 36(6), 749-769. https://doi.org/10.1002/job.2019

Humphrey, R. H., Pollack, J. M., \& Hawver, T. (2008). Leading with emotional labor. Journal of Managerial Psychology, 23(2), 151-168. https://doi.org/10.1108/02683940810850790

Iplik, F. M., Topsakal, Y., \& Iplik, E. (2014). The Effects of Emotional Labor on Job Attitudes of Hotel Employees: Mediating and Moderating Roles of Social Support and Job Autonomy. International Review of Management and Marketing, 4(3), 175186. Retrieved from www.econjournals.com

Kammeyer-Mueller, J. D., Rubenstein, A. L., Long, D. M., Odio, M. A., Buckman, B. R., Zhang, Y., \& Halvorsen-Ganepola, M. D. K. (2013). A Meta-Analytic Structural Model of Dispositonal Affectivity and Emotional Labor. Personnel Psychology, 66(1), 47-90. https://doi.org/10.1111/peps.12009

Kumadji, S., Kusumawati, A., \& Normasari, S. (2013). Pengaruh kualitas pelayanan terhadap kepuasan pelanggan, citra perusahaan, dan loyalitas pelanggan (The effect of service quality on costumer satisfaction, company image and costumer loyalty). Jurnal Administrasi Bisnis, 6, 1-9.

Martínez-Iñigo, D., Totterdell, P., Alcover, C. M., \& Holman, D. (2007). Emotional labour and emotional exhaustion: Interpersonal and intrapersonal mechanisms. Work \& Stress, 21(1), 30-47. https://doi.org/10.1080/02678370701234274

Nasional, B. P. P., \& (BAPPENAS). (2017). Peraturan Presiden Republik Indonesia Nomor 79 Tahun 2017 tentang Rencana Kerja Pemerintah tahun 2018. 1-231. Retrieved from https://www.bappenas.go.id/files/rkp/LAMPIRAN PERPRES RKP TAHUN 2018.pdf

Nuraningsih, N. L., \& Putra, M. S. (2015). Pengaruh kecerdasan emosional terhadap kepuasan kerja dan stress kerja pada The Seminyak Beach Resort and Spa (The effect of emotional intelligence on job satisfaction and job stress at The Seminyak Beach Resort and Spa). E-Jurnal Manajemen UNUD, 4(10), 2955-2981. Retrieved from https://ojs.unud.ac.id/index.php/Manajemen/article/view/13749

Pangemanan, F. L., Pio, R. J., \& Tumbel, T. M. (2017). Pengaruh work life balance dan 
burn out terhadap kepuasan kerja (The effect of work life balance and burn out on job satisfaction). Jurnal Administrasi Bisnis, https://doi.org/10.35797/JAB.5.003.2017.16718.\%P

Puspitawati, N. M. (2014). Pengaruh kepuasan kerja terhadap komitmen organisasional dan kualitas layanan (The effect of job satisfaction on organisational commitment and service quality). Manajemen Bisnis Dan Kewirausahaan, 68-80.

Robbins, S., \& Judge, T. (2013). Organizational Behavior. Retrieved from http://bba12.weebly.com/uploads/9/4/2/8/9428277/organizational_behavior_15e__stephen_p_robbins_timothy_a_judge_pdf_qwerty.pdf

Sugiyono. (2011). Metodologi penelitian kuantitatif kualitatif dan R\&D. Bandung: Alfabeta.

Tan, H. H., Foo, M. Der, \& Kwek, M. H. (2004). The Effects of Customer Personality Traits on the Display of Positive Emotions. Academy of Management Journal, 47(2), 287-296. https://doi.org/10.5465/20159579

Tsai, W. (2001). Knowledge transfer in intraorganizational networks: Effects of network position and absorptive capacity on business unit innovation and performance. Academy of Management Journal, 44(5), 996-1004. https://doi.org/10.2307/3069443

Yalcin, A. (2010). Emotional labor: dispositional antecedents and the role of affective events (Ankara: Ufuk University). Retrieved from https://etd.lib.metu.edu.tr/upload/12612507/index.pdf 